\title{
Influence of Selective Surface Oxidation of Si and Mn on Fe-Zn Alloying Reaction on Hot-rolled Steel Sheets
}

\author{
Masaki KOBA, ${ }^{*}$ Yusuke FUSHIWAKI and Yasunobu NAGATAKI \\ JFE Steel Corporation, 1, Koukan-cho, Fukuyama, 721-8510 Japan. \\ (Received on January 30, 2019; accepted on March 6, 2019; originally published in Tetsu-to-Hagané, \\ Vol. 104, 2018, No. 11, pp. 646-654)
}

\begin{abstract}
The Fe-Zn alloying reaction and selective oxidation behavior of 0.7 mass $\%$ Si-1.15 mass\% Mn added hot-rolled steel annealed at $600-800^{\circ} \mathrm{C}$ were investigated by comparison with those of cold-rolled steel. The Fe-Zn reactivity of the hot-rolled steel improved from $600^{\circ} \mathrm{C}$ to $700^{\circ} \mathrm{C}$ but deteriorated from $700^{\circ} \mathrm{C}$ to $800^{\circ} \mathrm{C}$. Above $700^{\circ} \mathrm{C}$, the amount of $\mathrm{Fe}-\mathrm{Si}-\mathrm{Mn}$ oxide on the steel surface increased with increasing temperature, and this oxide deteriorated Fe-Zn reactivity. Below $700^{\circ} \mathrm{C}$, a thin layer of Fe oxide on the steel surface deteriorated $\mathrm{Fe}-\mathrm{Zn}$ reactivity. This oxide layer was reduced by $\mathrm{Si}$ and $\mathrm{Mn}$ that diffused from the steel substrate. Therefore, as the temperature increased from $600^{\circ} \mathrm{C}$ to $700^{\circ} \mathrm{C}, \mathrm{Fe}-\mathrm{Zn}$ reactivity improved due to the formation of reduced iron on the steel surface. In the case of the cold-rolled steel, the same selective oxidation behavior and reduction mechanism of the Fe oxide were also confirmed, and as a result, the $\mathrm{Fe}-\mathrm{Zn}$ reactivity of the cold-rolled steel showed behavior similar to that of the hot-rolled steel. However, the Fe-Zn reactivity of the cold-rolled steel improved at a lower temperature than that of the hot-rolled steel. This can be explained by the faster diffusion rates of Si and $\mathrm{Mn}$ in the cold-rolled steel than in the hot-rolled steel. That is, reduction of the surface Fe oxide layer by diffused Si and Mn proceeded at a lower temperature, and as a result, the Fe-Zn reactivity of the cold-rolled steel also improved at a lower temperature.
\end{abstract}

KEY WORDS: Si; Mn; hot-rolled steel; selective surface oxidation; Fe-Zn alloying.

\section{Introduction}

Increasing demand for reduced automotive body weight and improved collision safety have greatly encouraged active use of high tensile strength steel sheets. ${ }^{1)}$ These sheets have also been galvanized or galvannealed to achieve excellent anti-corrosion properties.

The steel sheets used in the automotive body structure can be divided into cold-rolled steel sheets, which are mainly used for outer/inner panels, and hot-rolled steel sheets, which are mainly used in underbody parts. Recently, galvanized high tensile strength hot-rolled steel sheets have been demanded by many automakers for weight reduction of underbody parts. ${ }^{2}$ Since addition of $\mathrm{Si}$ and $\mathrm{Mn}$ is a valid way to achieve the required mechanical properties, a galvanizing method which is applicable to $\mathrm{Si}, \mathrm{Mn}$-added hot-rolled steel is highly demanded. ${ }^{3-5)}$

Although Si and Mn are also added to cold-rolled steel to secure mechanical properties, it is well known that these elements deteriorate galvanizability due to selective surface oxidation (element segregation) during the recrystallization annealing process. ${ }^{6-13)}$ In the case of hot-rolled steel, the factors that affect the galvanizability of high tensile strength hot-rolled steel sheets had not been investigated in detail,

\footnotetext{
* Corresponding author: E-mail: m-koba@jfe-steel.co.jp DOI: https://doi.org/10.2355/isijinternational.ISIJINT-2019-067
}

and most studies focused on the effect of the surface condition of hot-rolled steel which did not contain Si and Mn. ${ }^{14-27)}$ Moreover, a small number of studies have investigated the effect of surface roughness and residual scale on the galvanizability of Si-containing hot-rolled steel, but the factors that inhibit galvanizability remain to be clarified. ${ }^{28,29)}$

In addition, because hot-rolled steel has less rolling strain than cold-rolled steel, it is not necessary to anneal hot-rolled steel over the recrystallization temperature. This means that production is possible at a low annealing temperature at which selective oxidation of $\mathrm{Si}$ and $\mathrm{Mn}$ are considered to be suppressed. Therefore, the main focuses of this study are the galvanizability and selective oxidation behavior of Si, Mnadded hot-rolled steel when annealed at low temperature.

\section{Experimental}

Hot-rolled steel sheets containing 0.7 mass $\%$ Si-1.15 mass $\%$ Mn were used in the present study. The sheet thickness was $2.3 \mathrm{~mm}$, and the chemical composition of the steel sheets was as shown in Table 1. To compare the difference

Table 1. Chemical composition of specimen (mass $\%$ ).

\begin{tabular}{cccccc}
\hline & $\mathrm{C}$ & $\mathrm{Si}$ & $\mathrm{Mn}$ & $\mathrm{P}$ & $\mathrm{Al}$ \\
\hline Steel & 0.08 & 0.7 & 1.15 & 0.015 & 0.04 \\
\hline
\end{tabular}


between this steel sheet and the cold-rolled steel sheet produced from it, the hot-rolled steel sheets were ground to a thickness of $1.2 \mathrm{~mm}$, and the unground surface was evaluated. A cold-rolled steel sample was prepared by rolling hot-rolled steel sheets to a thickness of $1.2 \mathrm{~mm}$. Both the hot-rolled and cold-rolled steel samples were precleaned by electric degreasing in an alkaline solution of 3 mass $\%$ $\mathrm{NaOH}$ at $500 \mathrm{~A} \cdot \mathrm{m}^{-2}$ for $10 \mathrm{~s}$. The samples were then pickled in an acidic solution of 5 mass $\% \mathrm{HCl}$ at $60^{\circ} \mathrm{C}$ for $6 \mathrm{~s}$, after they were annealed. Annealing was carried out in an atmosphere of $\mathrm{N}_{2}+10 \% \mathrm{H}_{2}$ at a dew point of $-35^{\circ} \mathrm{C}$. The heating rate was $10^{\circ} \mathrm{C} \cdot \mathrm{s}^{-1}$ up to $400^{\circ} \mathrm{C}$ followed by heating to the maximum temperature $\left(600-800^{\circ} \mathrm{C}\right)$ in $120 \mathrm{~s}$. The soaking time at the maximum temperature was $20 \mathrm{~s}$. After annealing, the samples were rapidly cooled $\left(10^{\circ} \mathrm{C} \cdot \mathrm{s}^{-1}\right)$ to $460^{\circ} \mathrm{C}$ and dipped in a molten 0.14 mass $\% \mathrm{Al}-\mathrm{Zn}$ bath. Some of the samples were cooled without dipping in order to analyze the surface condition of the annealed samples. In addition, in order to investigate the temperature dependence of surface selective oxidation, some samples were annealed with the heating rate $12^{\circ} \mathrm{C} \cdot \mathrm{s}^{-1}$ up to the maximum temperature $\left(600-700^{\circ} \mathrm{C}\right)$ and isothermally heated for an arbitrary time (20-600 s).

In the previous studies, the galvanizability of steel sheets was evaluated by a coating grade rating ${ }^{28,29)}$ or the numbers of coating defects per unit area. ${ }^{30,31)}$ However, both methods were limited to evaluation of the sample appearance, and the reaction between the $\mathrm{Zn}$ coating and the base steel was not investigated. Therefore, in this study, the reaction between the $\mathrm{Zn}$ coating and the base steel was evaluated by observation $\mathrm{Fe}-\mathrm{Zn}$ alloy area on the steel surface. A schematic of the Fe-Zn reactivity evaluation by electrical dissolution is shown in Fig. 1. When selectively oxidized $\mathrm{Si}$ or $\mathrm{Mn}$ existed on the steel surface (Fig. 1(a)), the Fe-Zn alloying reaction was suppressed (Fig. 1(b)). In order to investigate the unreacted area on the steel surface, electrical dissolution was used to reveal the $\mathrm{Fe}-\mathrm{Zn}$ alloy by dissolving only the $\eta$ phase (Fig. 1(c)). Fe-Zn reactivity was evaluated based on the observation results of the coverage rate of the $\mathrm{Fe}-\mathrm{Zn}$ alloy on the steel substrate. The Fe-Zn alloy was revealed by electrical dissolution in a solution of 4 mass $\%$ methyl salicylate-1 mass $\%$ salicylate acid-10 mass \% KI-methanol at $-750 \mathrm{mV}$ and $200 \mathrm{~A} \cdot \mathrm{m}^{-2}$.

The annealed samples were analyzed as follows. Selective surface oxidation behavior was investigated by glow discharge optical emission spectroscopy (GDS). A schematic of the GDS measurement results is shown in Fig. 2. The amount of selective surface oxidation of the annealed samples was quantified by measuring the concentration pro- files of $\mathrm{Si}, \mathrm{Mn}$ at the steel surface by GDS. In these GDS profiles, the integrated $\mathrm{Si}, \mathrm{Mn}$ intensity (arbitrary unit) from the steel surface to the minimal intensity was defined as the amount of selective oxidation.

The morphology of selective surface oxidation of the annealed samples was observed by scanning electron microscopy (SEM). The conditions used in this observation were an acceleration voltage of $1 \mathrm{kV}$ and working distance of $2.4 \mathrm{~mm}$. In order to investigate cross-sectional samples of the annealed samples, samples were prepared by focused ion beam (FIB) milling to a thickness of $100 \mathrm{~nm}$. The samples were investigated by transmission electron microscopy (TEM) to determine the morphology and distribution of the oxides in the subsurface region. In addition, to confirm the factors that deteriorated galvanizability, cross-sectional samples of bare spots on the galvanized samples were also prepared by FIB milling and investigated by TEM.

Determination of the composition of the surface oxides was performed by energy dispersive spectroscopy (EDS) and X-ray photoelectron spectroscopy (XPS). To prepare the samples for XPS analysis, the samples were immediately placed in vacuum storage after annealing to avoid oxidation and corrosion in the atmosphere. Characterization of the species of the oxides on the steel surface was performed using standard oxides powders (Kojundo Chemical Laboratory) as reference samples.

\section{Results}

3.1. Effect of Annealing Temperature on Galvanizability Figure 3 shows the results of observation of the galva-

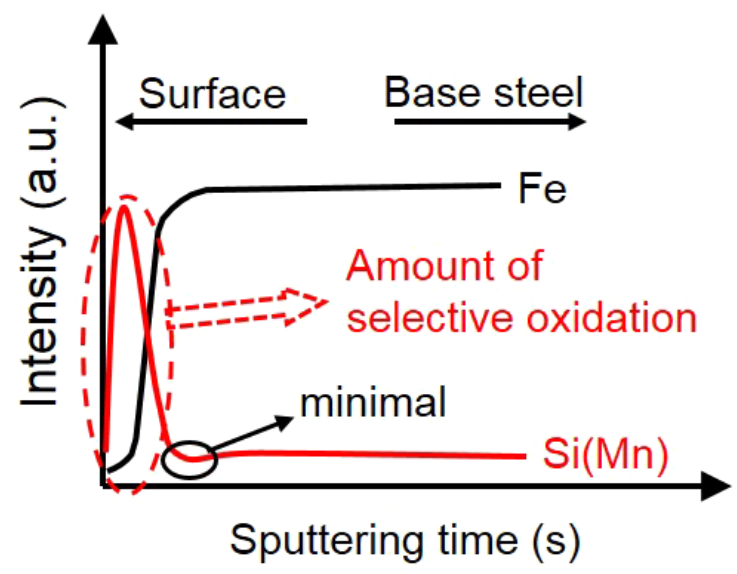

Fig. 2. Schematic of GDS depth profile of surface of Si(Mn) containing steel after annealing. (Online version in color.) (a)

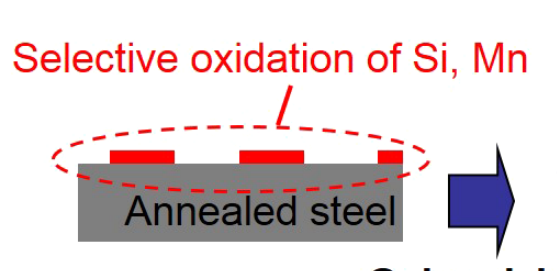

Galvanizing (b)

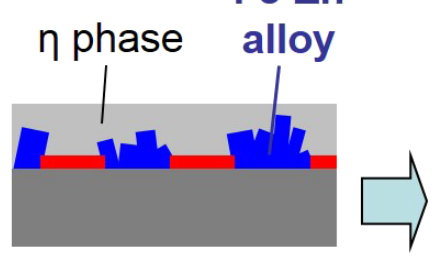

Electrical dissolution

Fig. 1. Schematic of evaluation of reactivity of $\mathrm{Zn}$ coating by electrical dissolution. (Online version in color.) 


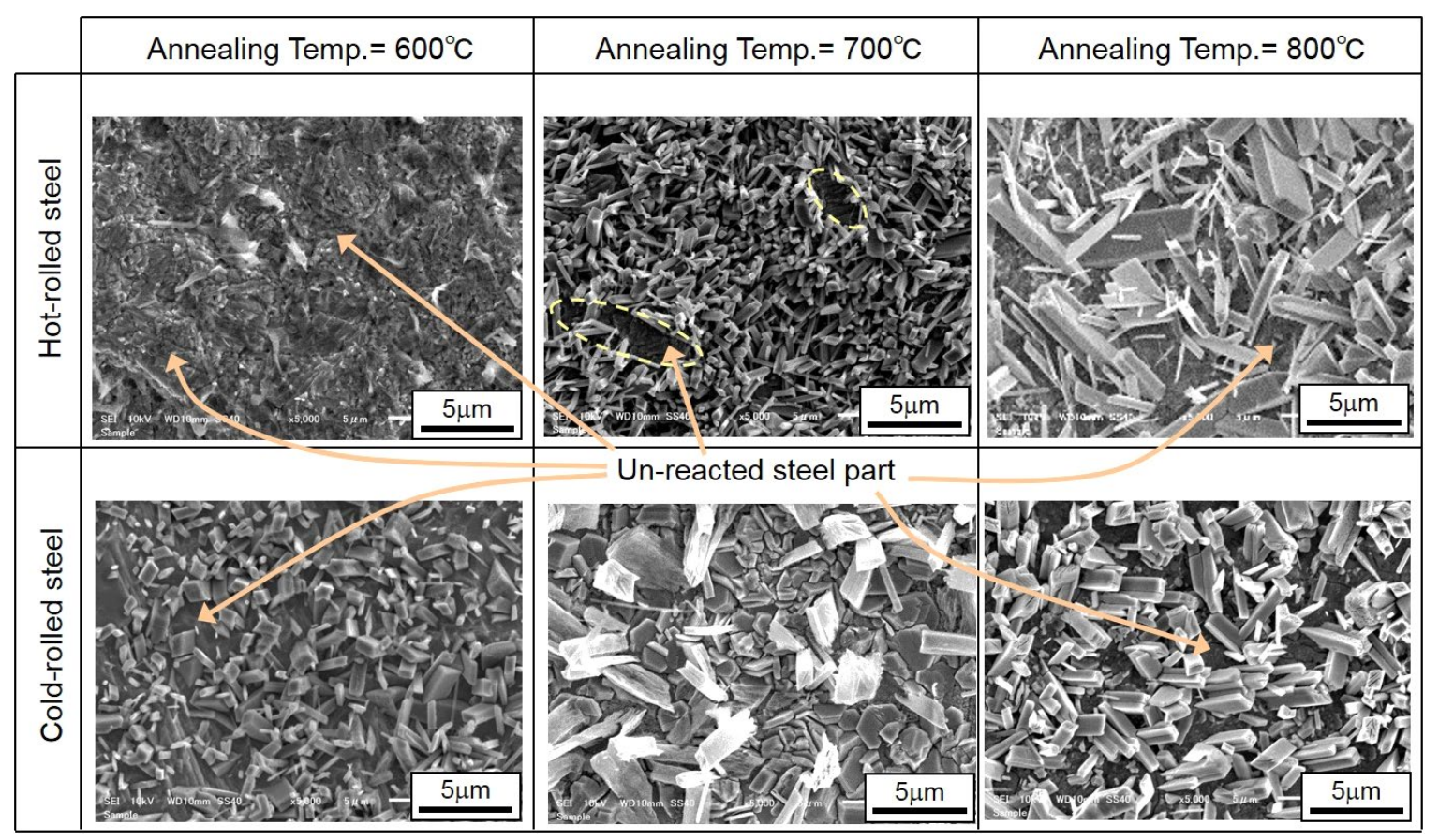

Fig. 3. SEM images of $\mathrm{Fe}-\mathrm{Zn}$ alloy formed on surface of galvanized steel observed by $10 \mathrm{kV}$ SEM. (Online version in color.)

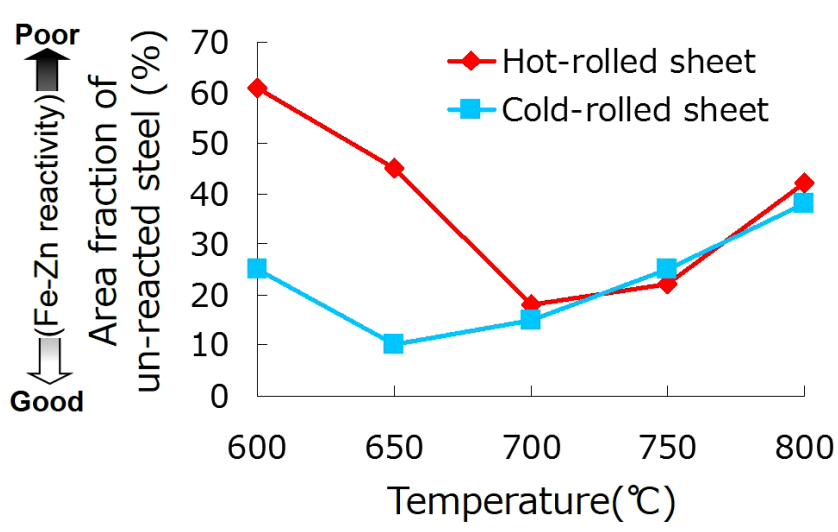

Fig. 4. Effect of annealing temperature on $\mathrm{Zn}$ coating reactivity of hot-rolled and cold-rolled steels. (Online version in color.)

nized samples after electrical dissolution. The pillar-shaped precipitates in the figure are the Fe-Zn alloy, and the region where no alloy was detected represents an unreacted part. Figure 4 shows the calculation results of the area fraction of the unreacted part. In the case of the hot-rolled steel, the unreacted area fraction decreased as the annealing temperature increased from $600^{\circ} \mathrm{C}$ to $700^{\circ} \mathrm{C}$, indicating that galvanizability improved. On the other hand, the unreacted area fraction increased and galvanizability deteriorated from $700^{\circ} \mathrm{C}$ to $800^{\circ} \mathrm{C}$. With the cold-rolled steel, the unreacted area fraction decreased from $600^{\circ} \mathrm{C}$ to $650^{\circ} \mathrm{C}$ but increased from $650^{\circ} \mathrm{C}$ to $800^{\circ} \mathrm{C}$. These results suggest that factors causing deterioration of galvanizability exist under both low and high annealing temperature conditions.

\subsection{Selective Surface Oxidation Behavior of Si, Mn on Annealed Steel Surface}

The selective oxidation behavior of $\mathrm{Si}, \mathrm{Mn}$ on the annealed steel surface was investigated to clarify the influence of selectively oxidized $\mathrm{Si}$ and $\mathrm{Mn}$ on $\mathrm{Fe}-\mathrm{Zn}$ reactiv- ity. Figure 5 shows the GDS depth profiles of the surfaces of the hot-rolled and cold-rolled steels with annealing at $600^{\circ} \mathrm{C}, 700^{\circ} \mathrm{C}$ and $800^{\circ} \mathrm{C}$. With both the hot-rolled and cold-rolled steels, no selective oxidation was detected before annealing. However, on the annealed steel surfaces, selectively oxidized peaks of $\mathrm{Si}$ and $\mathrm{Mn}$ were observed at several tens of nano-meters from the surface, and these peaks became remarkable with increasing annealing temperature. Figure 6 shows the relationship between annealing temperature and the amount of selective oxidation of Si and Mn of the annealed steel samples. Selective oxidation of both $\mathrm{Si}$ and $\mathrm{Mn}$ increased with increasing annealing temperature. However, the amount of selective oxidation of the hotrolled steel was smaller than that of the cold-rolled steel. For example, in the case of annealing at $600^{\circ} \mathrm{C}$, selective oxidation peaks were observed on the cold-rolled steel, but no peaks were detected on the hot-rolled steel.

Figure 7 shows the results of SEM observation of the annealed steel surfaces. No precipitates were observed on the surface of hot-rolled steel annealed at the temperatures of $600^{\circ} \mathrm{C}$ and $650^{\circ} \mathrm{C}$, but orbicular precipitates were observed at temperatures over $700^{\circ} \mathrm{C}$. On annealed coldrolled steel, no precipitates were observed at $600^{\circ} \mathrm{C}$, and orbicular precipitates were observed at temperatures over $650^{\circ} \mathrm{C}$. EDS analysis revealed that the compositions of these orbicular precipitates were $\mathrm{Si}-\mathrm{Mn}-\mathrm{Fe}$-containing oxides.

XPS was also used to characterize the oxides on the annealed steel surfaces. The results are shown in Fig. 8. $\mathrm{Fe}_{2} \mathrm{SiO}_{4}, \mathrm{Mn}_{2} \mathrm{SiO}_{4}$ and $\mathrm{MnSiO}_{3}$ were used as reference samples, and binding energy of $\mathrm{Si} 2 \mathrm{p}$ was detected. Since $\mathrm{Fe}_{2} \mathrm{SiO}_{4}$ and $\mathrm{Mn}_{2} \mathrm{SiO}_{4}$ show almost the same energy (101.6 $\mathrm{eV})$ and $\mathrm{MnSiO}_{3}$ also shows relatively similar energy (102.0 $\mathrm{eV})$, the binding energies of these oxides are represented as $\mathrm{SiO}_{\mathrm{x}}{ }^{\mathrm{n}-}$ in Fig. 8. According to the spectrum of $\mathrm{Mn} 2 \mathrm{p}$ and Si $2 p$ in both the hot-rolled and cold-rolled steels, no Mn oxide and a slight $\mathrm{SiO}_{\mathrm{x}}{ }^{\mathrm{n}-}$ peak were detected before anneal- 


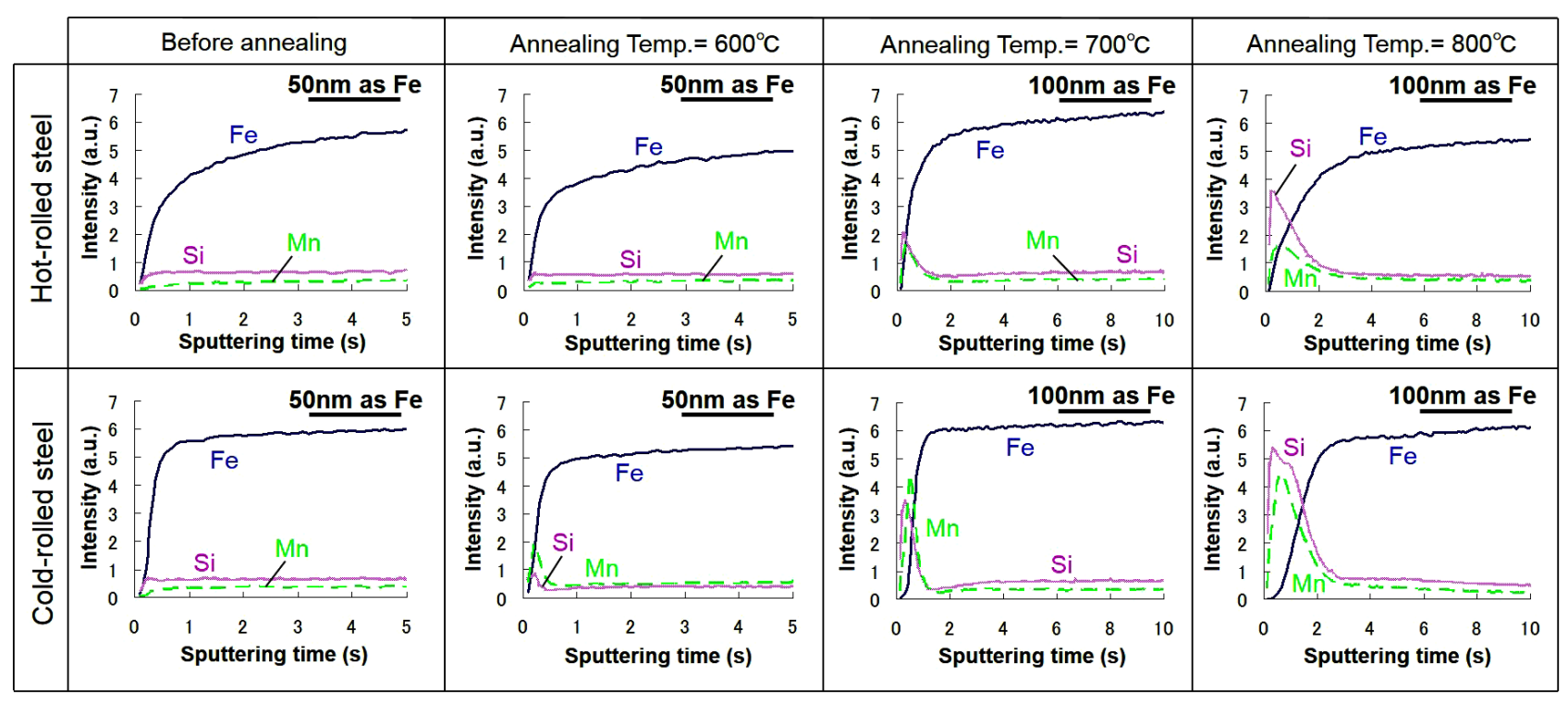

Fig. 5. GDS depth profiles of surfaces of hot-rolled and cold-rolled steels with/without annealing at $600^{\circ} \mathrm{C}, 700^{\circ} \mathrm{C}$ and $800^{\circ} \mathrm{C}$. (Online version in color.)

(a)

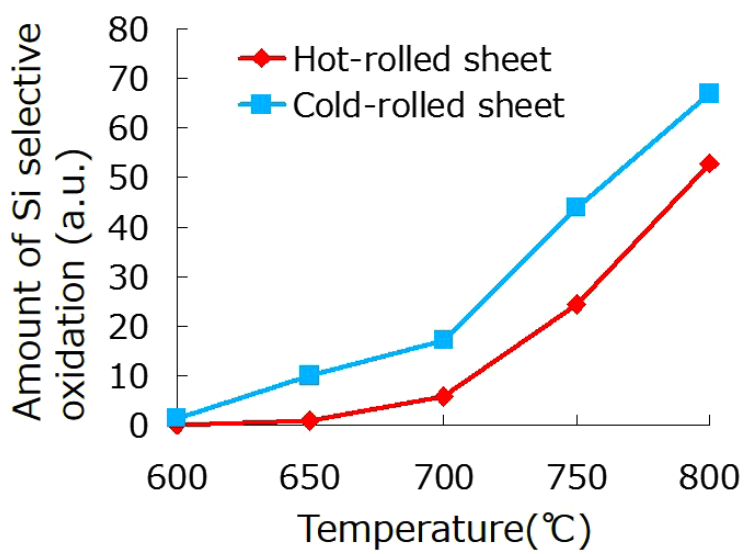

(b)

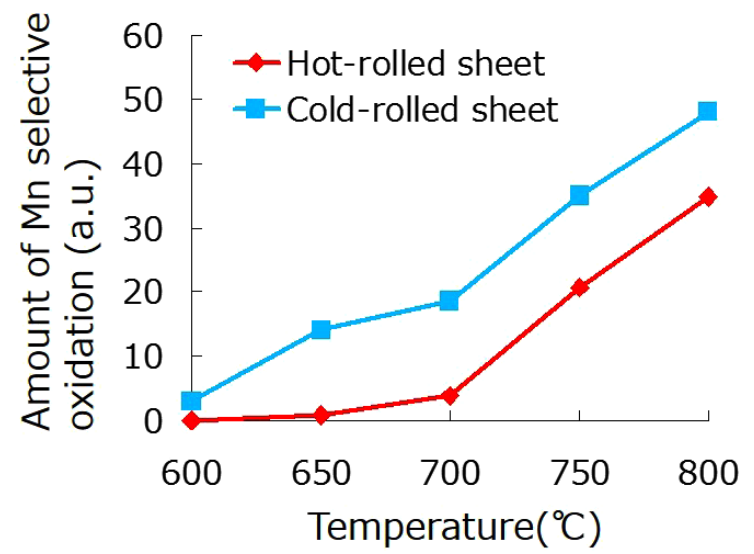

Fig. 6. Si and $\mathrm{Mn}$ selective surface oxidation behavior of hot-rolled and cold-rolled steels annealed at $600-800^{\circ} \mathrm{C}$. (Online version in color.)

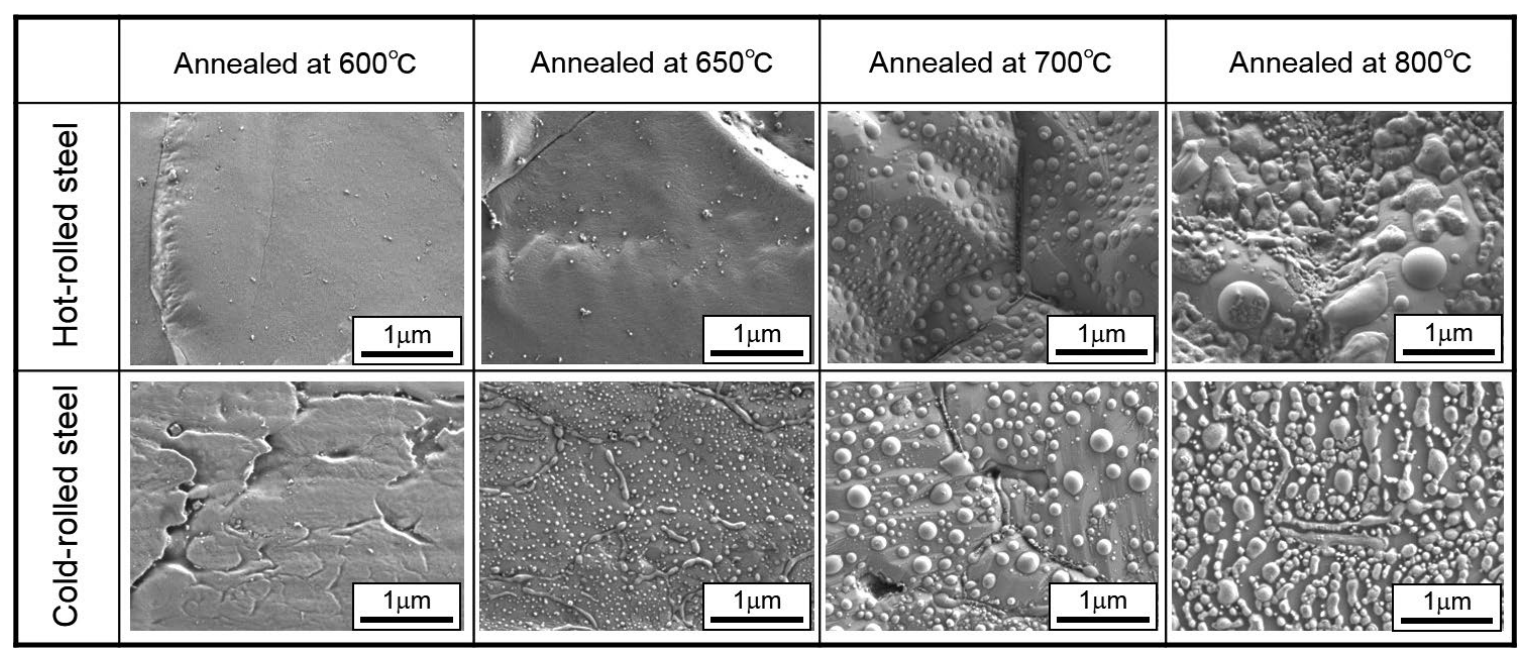

Fig. 7. SEM images of surfaces of hot-rolled and cold-rolled steels annealed at $600^{\circ} \mathrm{C}, 650^{\circ} \mathrm{C}, 700^{\circ} \mathrm{C}$ and $800^{\circ} \mathrm{C}$ observed by $1 \mathrm{kV}$ SEM.

ing, and the existence of an $\mathrm{Fe}-\mathrm{Si}$ oxide with no Mn content was suggested. However, the peak of $\mathrm{Fe}-\mathrm{O}$ was mainly detected in the spectrum of $\mathrm{Fe} 2 \mathrm{p}$ before annealing, and the main oxide on the hot-rolled and cold-rolled steels before annealing was confirmed to be Fe oxide. In both the hotrolled and cold-rolled steels, the peaks of $\mathrm{SiO}_{\mathrm{x}}{ }^{\mathrm{n}-}$ and $\mathrm{Mn}-\mathrm{O}$ 


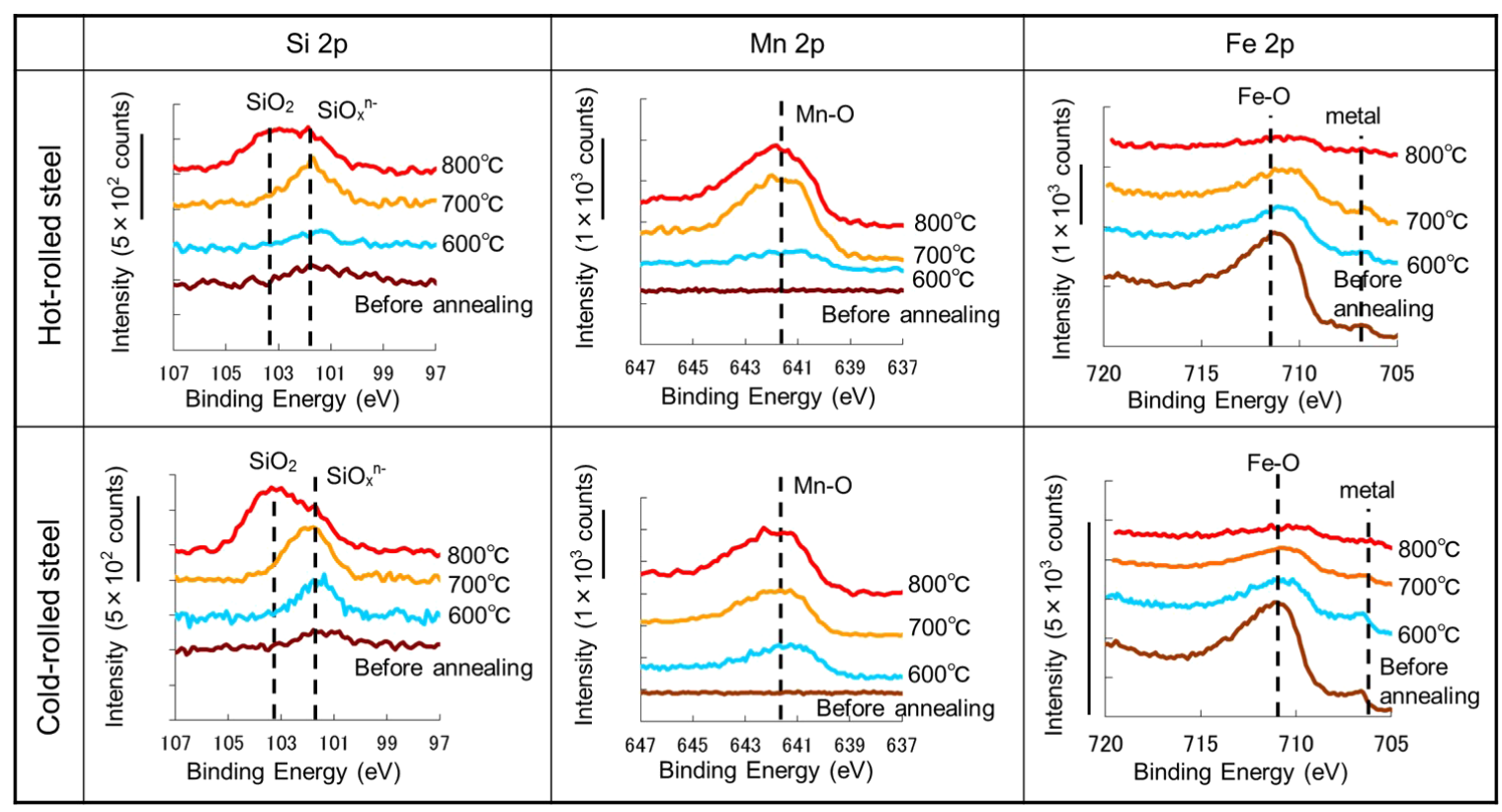

Fig. 8. XPS spectra of surfaces of annealed hot-rolled and cold-rolled steels. (Online version in color.)

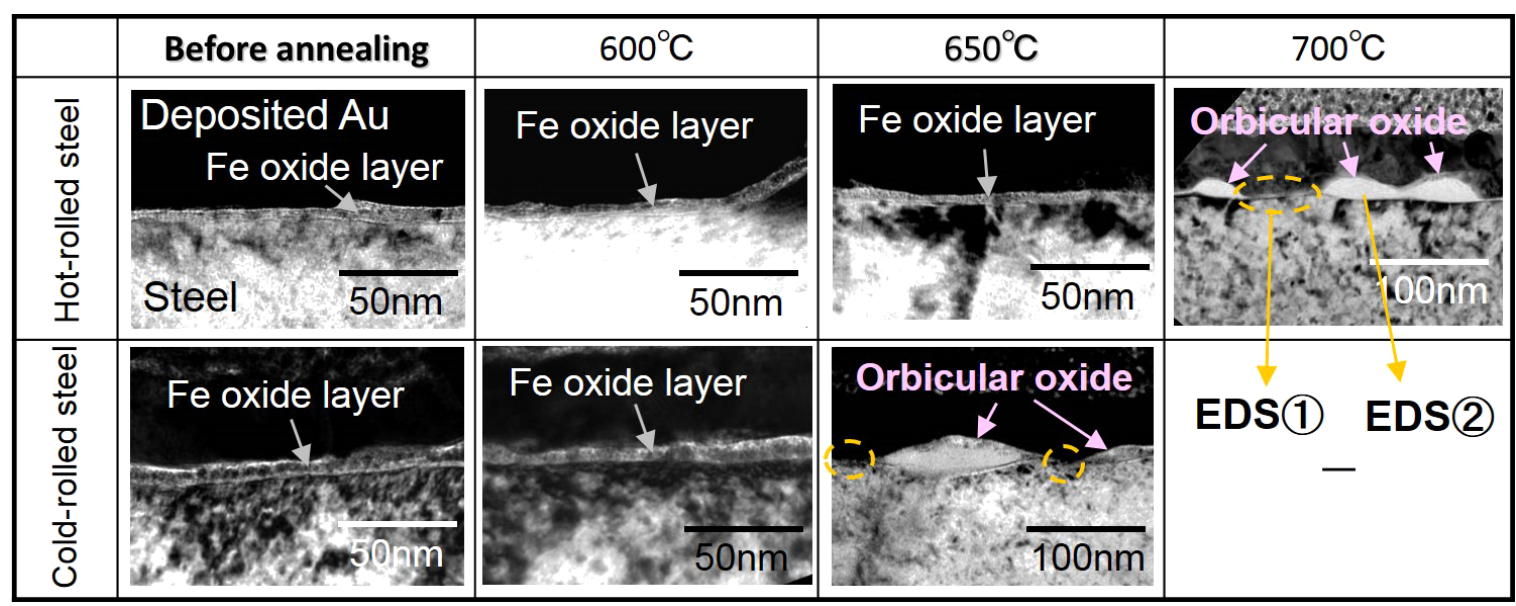

Fig. 9. Cross-sectional TEM images of surfaces of hot-rolled and cold-rolled steels with/without annealing at $600^{\circ} \mathrm{C}$, $650^{\circ} \mathrm{C}$ and $700^{\circ} \mathrm{C}$. (Online version in color.)

increased with increasing temperature, and these oxides are considered to be the orbicular oxides observed in Fig. 7. In addition, $\mathrm{SiO}_{2}$ was detected after annealing at $800^{\circ} \mathrm{C}$. According to the spectra of $\mathrm{Fe} 2 \mathrm{p}$ in both the hot-rolled and cold-rolled steels, the Fe oxide which was the main oxide before annealing decreased proportionally with the formation of $\mathrm{SiO}_{\mathrm{x}}{ }^{\mathrm{n}-}$, and almost no Fe oxide was detected after annealing at $800^{\circ} \mathrm{C}$.

\subsection{Morphology of Oxides on Steel Surface at Low Annealing Temperature}

From the investigations described above, a slight amount of Fe oxide was suggested to exist on the steel surface after low temperature annealing. In order to clarify the morphology of the Fe oxide on the surface of the annealed sample, cross-sectional TEM observations were performed. At the same time, the composition of the oxide was investigated by EDS. The results are shown in Fig. 9. On the surfaces of both the hot-rolled and cold-rolled steels before/after annealing at $600^{\circ} \mathrm{C}$, uniformly sized thin $\mathrm{Fe}$ oxide layers which contained a slight amount of $\mathrm{Si}, \mathrm{Mn}$ were identi-
Table 2. Chemical composition at point marked in Fig. 9 (mol\%).

\begin{tabular}{ccccc}
\hline & $\mathrm{Fe}$ & $\mathrm{Si}$ & $\mathrm{Mn}$ & $\mathrm{O}$ \\
\hline EDS(1) & 96.8 & 0.0 & 0.3 & 2.9 \\
EDS(2) & 13.2 & 20.8 & 16.5 & 49.5 \\
\hline
\end{tabular}

fied. As the temperature increased, the morphology of the Fe oxide layer changed to island-shaped precipitates. This change occurs at the temperatures of $700^{\circ} \mathrm{C}$ on the annealed sample of the hot-rolled steel and at $650^{\circ} \mathrm{C}$ on the annealed cold-rolled steel. From the EDS analysis results shown in Table 2, these island-shaped precipitates were confirmed to be $\mathrm{Fe}-\mathrm{Si}-\mathrm{Mn}$-containing oxides. In the region surrounded by the island-shaped precipitates (circled area in the figure), the Fe oxide layer had almost disappeared, and the steel surface was exposed.

To confirm the influence of this change in the morphology of the oxides on the wettability of the $\mathrm{Zn}$ coating, crosssectional TEM observation of the interface between a bare spot and galvanized area was performed. Figure 10 shows 


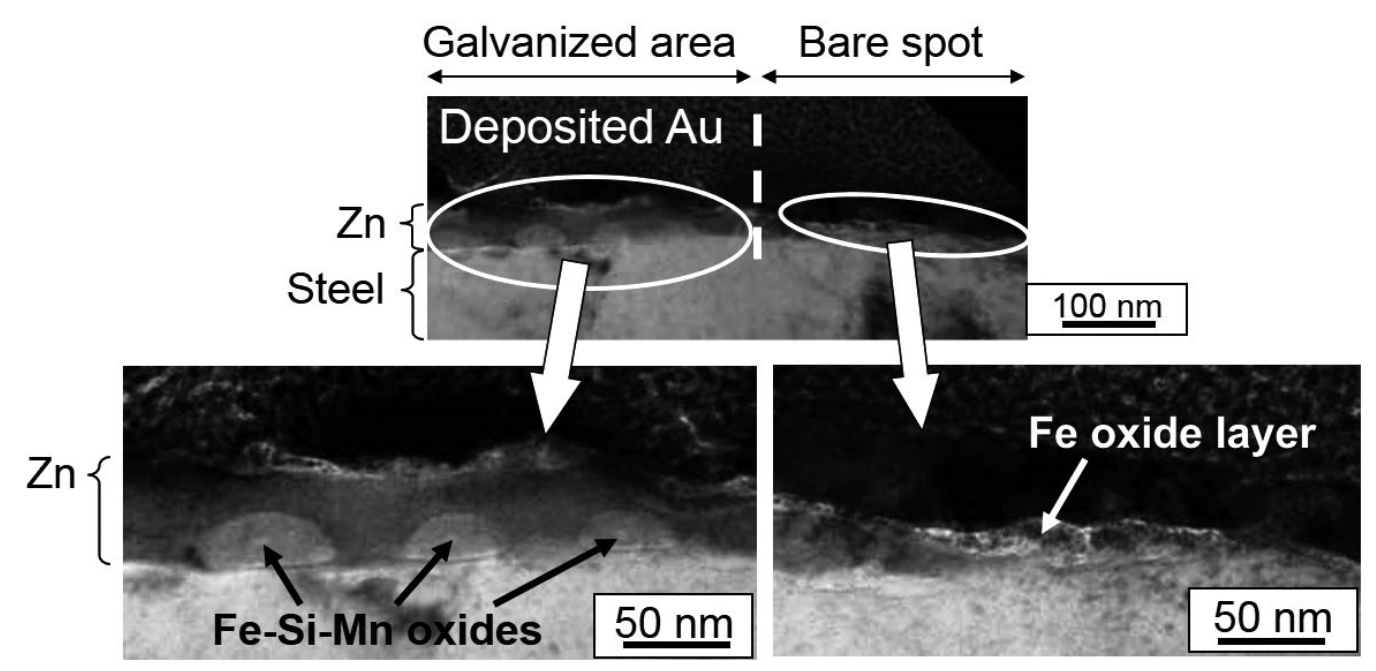

Fig. 10. Result of TEM observation of interface between bare spot and galvanized area.

the results of observation of the galvanized cold-rolled steel after $650^{\circ} \mathrm{C}$ annealing, at which the formation of orbicular oxides was observed. In the bare spot, no $\mathrm{Si}-\mathrm{Mn}$ orbicular oxides were observed, but a thin Fe oxide layer was observed. On the other hand, $\mathrm{Si}-\mathrm{Mn}$ orbicular oxides were observed in the galvanized area.

\section{Discussion}

\subsection{Change in Amount of Selective Surface Oxidation with Annealing Temperature and Its Effect on Fe- Zn Reactivity}

The effect of selective surface oxidation on wettability in galvanizing has been investigated in many studies, which found that selective surface oxidation of $\mathrm{Si}$ and $\mathrm{Mn}$ deteriorates galvanizability. ${ }^{6-13)}$ In order to clarify the effect of selective surface oxidation on $\mathrm{Fe}-\mathrm{Zn}$ reactivity, in this study, the relationship between the unreacted area fraction (Fig. 4) and the amount of selective surface oxidation (Fig. 6) was considered. According to Fig. 6, the temperature dependence of $\mathrm{Si}$ and $\mathrm{Mn}$ selective oxidation were almost same, and Fig. 11 shows the relationship between unreacted area fraction and the amount of Si selective oxidation (a.u.). A shaded area in the figure represents the conditions of the minimum unreacted area fraction (hot-rolled steel: $700^{\circ} \mathrm{C}$, cold-rolled steel: $650^{\circ} \mathrm{C}$ ) in this study.

The $\mathrm{Fe}-\mathrm{Zn}$ reactivity of the cold-rolled steel deteriorated with increasing temperature above $650^{\circ} \mathrm{C}$. This result coincided with the results of previous studies showing that selective surface oxidation of $\mathrm{Si}$ and $\mathrm{Mn}$ deteriorate $\mathrm{Fe}-\mathrm{Zn}$ reactivity. However, in the case of the hot-rolled steel, $\mathrm{Fe}-$ $\mathrm{Zn}$ reactivity deteriorated with increasing temperature above $700^{\circ} \mathrm{C}$. Thus, the results of this investigation suggested that $\mathrm{Fe}-\mathrm{Zn}$ reactivity has a good correlation with the amount of $\mathrm{Si}, \mathrm{Mn}$ selective oxidation above an annealing temperature of $700^{\circ} \mathrm{C}$.

However, in the low annealing temperature region indicated by the circle in Fig. 11, the Fe-Zn reactivities of both the hot-rolled steel and the cold-rolled steel deteriorated. This suggests that some deteriorating factor other than selective oxidation exists in the low annealing temperature region. Therefore, the deteriorating factors of $\mathrm{Fe}-\mathrm{Zn}$ reactivity at low annealing temperatures are considered in the

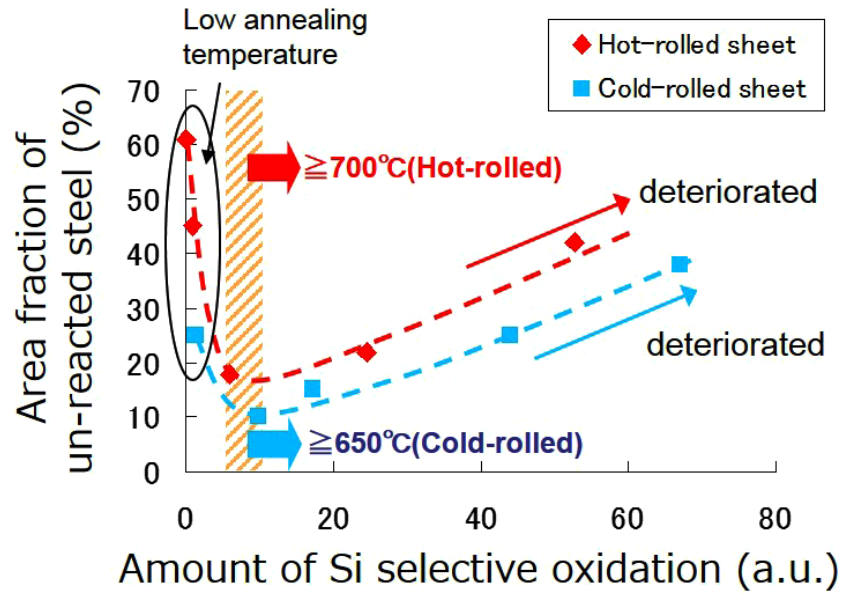

Fig. 11. Relationship between amount of Si selective oxidation and $\mathrm{Zn}$ coating reactivity of hot-rolled and cold-rolled steels. (Online version in color.)

following section.

\subsection{Factors Affecting Galvanizability at Low Anneal- ing Temperature}

From the XPS results in Fig. 8, Fe oxide existed on the surfaces of both the hot-rolled and cold-rolled steels before annealing. There were no differences in both the composition and morphology of these oxides in the hot-rolled and cold-rolled steels, and these oxide films were suggested to be native Fe oxide. It has been reported that these oxide layers deteriorate galvanizability. ${ }^{32)}$ Especially at low annealing temperatures, the Fe oxide layer was found to cover the steel surface as shown in Fig. 9. Therefore, this residual Fe oxide layer is considered to be a main deteriorating factor at low annealing temperatures.

Then, the mechanism by which the $\mathrm{Fe}-\mathrm{Zn}$ reactivities of the hot-rolled steel and cold-rolled steel were improved with increasing temperature was considered. During the annealing process, surface selective oxidation was considered to occur by the reaction of diffused $\mathrm{Si}, \mathrm{Mn}$ from the steel substrate and the dissociated oxide from $\mathrm{H}_{2} \mathrm{O}$ in the atmosphere. ${ }^{33)}$ However, if the steel surface is covered by an $\mathrm{Fe}$ oxide layer, the diffused $\mathrm{Si}$ and $\mathrm{Mn}$ may have the potential to react with the residual Fe oxide. To confirm this 
hypothesis, the following reactions in connection with the oxidation of $\mathrm{Si}$ and $\mathrm{Mn}$-bearing steel in an atmosphere with $\mathrm{H}_{2}-\mathrm{H}_{2} \mathrm{O}$ were calculated.

$$
\begin{array}{r}
\mathrm{Fe}+\mathrm{H}_{2} \mathrm{O}=\mathrm{FeO}+\mathrm{H}_{2} \ldots \ldots \ldots . . . \\
2 \mathrm{Fe}+\mathrm{SiO}_{2}+2 \mathrm{H}_{2} \mathrm{O}=\mathrm{Fe}_{2} \mathrm{SiO}_{4}+2 \mathrm{H}_{2} \\
\mathrm{Mn}+\mathrm{H}_{2} \mathrm{O}=\mathrm{MnO}+\mathrm{H}_{2} \ldots \ldots \ldots . . . \\
\mathrm{Mn}+\mathrm{SiO}_{2}+\mathrm{H}_{2} \mathrm{O}=\mathrm{MnSiO}_{3}+\mathrm{H}_{2} \ldots \\
\mathrm{Si}+2 \mathrm{H}_{2} \mathrm{O}=\mathrm{SiO}_{2}+2 \mathrm{H}_{2} \ldots \ldots \ldots . . .
\end{array}
$$

$\mathrm{p}_{\mathrm{H}_{2} \mathrm{O}} / \mathrm{p}_{\mathrm{H}_{2}}$ is defined as the ratio of the partial pressure of $\mathrm{H}_{2} \mathrm{O}\left(\mathrm{p}_{\mathrm{H}_{2} \mathrm{O}}\right)$ and that of $\mathrm{H}_{2}\left(\mathrm{p}_{\mathrm{H}_{2}}\right) \cdot \mathrm{p}_{\mathrm{H}_{2} \mathrm{O}} / \mathrm{p}_{\mathrm{H}_{2}}$ of each oxide was calculated considering the above Eqs. (1) through (5) for an $\mathrm{Fe}-0.7$ mass\% $\mathrm{Si}-1.15$ mass\% Mn alloy annealed in an atmosphere of $10 \mathrm{vol} \% \mathrm{H}_{2}-\mathrm{N}_{2} .{ }^{34,35)}$ The results are shown in Fig. 12. $\log \left(\mathrm{p}_{\mathrm{H}_{2} \mathrm{O}} / \mathrm{p}_{\mathrm{H}_{2}}\right)$ could be calculated at about -2.66 in the annealing atmosphere, which had a dew point of $-35^{\circ} \mathrm{C}$ and a hydrogen concentration of 10 vol\%. As shown in Fig. 12, when $\log \left(\mathrm{p}_{\mathrm{H}_{2} \mathrm{O}} / \mathrm{p}_{\mathrm{H}_{2}}\right)$ equals -2.66 , the reaction in Eqs. (1) and (2) should proceed to the left, and Eqs. (3) through (5) should proceed to the right. These results also suggest that $\mathrm{Si}-\mathrm{Mn}$ composite oxides are more stable than Fe oxide. Therefore, when the surface of the steel is covered by an Fe oxide layer, diffused $\mathrm{Si}$ and $\mathrm{Mn}$ have the potential to react with the residual $\mathrm{Fe}$ oxide. This indicates that the following reaction occurred at the steel surface under the low annealing temperature conditions.

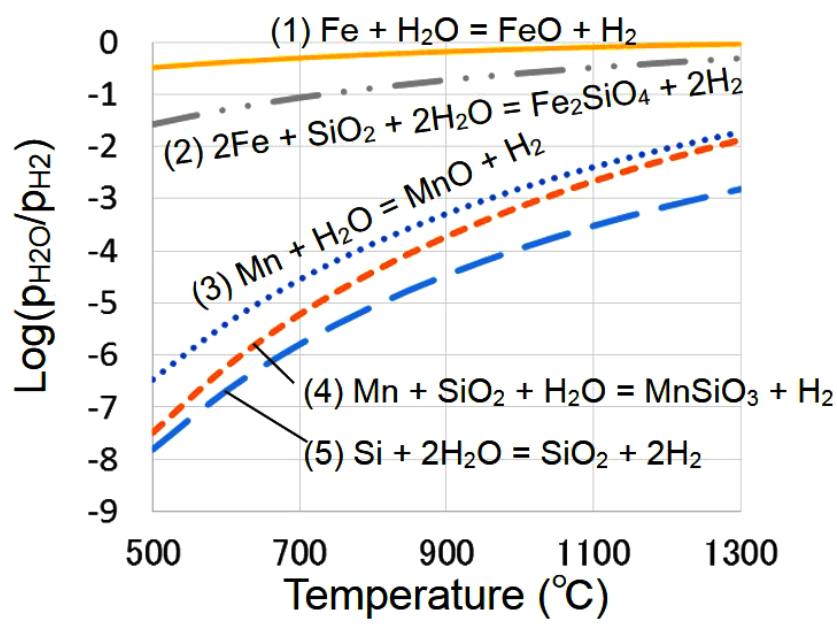

Fig. 12. Equilibrium $\mathrm{p}_{\mathrm{H}_{2} \mathrm{O}} / \mathrm{p}_{\mathrm{H}_{2}}$ of various oxides on steel containing $0.7 \% \mathrm{Si}$ and $1.15 \% \mathrm{Mn}$ with annealing in $\mathrm{H}_{2}-\mathrm{H}_{2} \mathrm{O}$ mixed gas atmosphere. (Online version in color.)

$$
\mathrm{FeO}_{\mathrm{n}}+\mathrm{y} \mathrm{Mn}+\mathrm{z} \mathrm{Si} \rightarrow \mathrm{Fe}_{(1-\mathrm{x})} \mathrm{Mn}_{\mathrm{y}} \mathrm{Si}_{\mathrm{z}} \mathrm{O}_{\mathrm{n}}+\mathrm{x} \mathrm{Fe}
$$

According to Eq. (6), Fe oxide is reduced and active Fe is produced during the oxidation of $\mathrm{Si}$ and $\mathrm{Mn}$. This $\mathrm{Si}-\mathrm{Mn}$ composite oxide tends to form in an orbicular shape. ${ }^{36}$ Therefore, when the reduction of $\mathrm{Fe}$ oxide proceeded as shown in Eq. (6) with increasing temperature, active Fe was produced with the formation of $\mathrm{Si}-\mathrm{Mn}$ composite orbicular oxides, and $\mathrm{Fe}-\mathrm{Zn}$ reactivity was considered to be improved. This result can explain the phenomenon shown in Fig. 10 that no $\mathrm{Si}-\mathrm{Mn}$ orbicular oxides were detected but a thin $\mathrm{Fe}$ oxide layer was observed in the bare spot area where $\mathrm{Fe}-\mathrm{Zn}$ reactivity may be lowest on the steel surface, while $\mathrm{Si}-\mathrm{Mn}$ orbicular oxides were observed in the galvanized area. Figure 13 shows schematic illustrations of the reduction mechanism of the Fe oxide layer at low annealing temperatures.

\subsection{Rate-determining Process of Surface Segregation at Low Annealing Temperature}

In this section, the $\mathrm{Fe}-\mathrm{Zn}$ reactivity of the hot-rolled steel was substantially worse than that of the cold-rolled steel in the low annealing temperature region. In addition, the temperatures at which $\mathrm{Fe}-\mathrm{Zn}$ reactivity improved were also different between the hot-rolled and cold-rolled steels. However, the species of the oxides and the reduction mechanism of the Fe oxide on the hot-rolled and cold-rolled steels were the same. Therefore, the difference in $\mathrm{Fe}-\mathrm{Zn}$ reactivity between the hot-rolled steel and the cold-rolled steel at low annealing temperatures was considered to be due to the difference in the reduction rate of Fe oxide, that is, the difference in the segregation rates of $\mathrm{Si}$ and $\mathrm{Mn}$. Selective surface oxidation consists of two different processes: One is the diffusion of the element concerned from the steel substrate, and the other is the reaction with the atmosphere on the steel surface. Therefore, the difference in the segregation rates is considered to be due to the "diffusion rate," which depends on the structure of the steel surface, or the "reaction rate," which depends on the steel surface condition.

First, the possibility of a difference in the diffusion rate of $\mathrm{Si}$ and $\mathrm{Mn}$ in the hot-rolled steel and cold-rolled steel was investigated. There are cases in which the diffusion rate in the steel subsurface region changes. One is the existence of a $\mathrm{Si}$ - and $\mathrm{Mn}$-depleted area in the steel subsurface region; in this case, diffusion of these elements is suppressed. ${ }^{37-39)}$ The other is a change in the structure of the steel surface due to the strain that occurs in the cold-rolling process, in this case diffusion of the elements is accelerated. ${ }^{40-43)}$ As for the former case, because no depleted area was observed

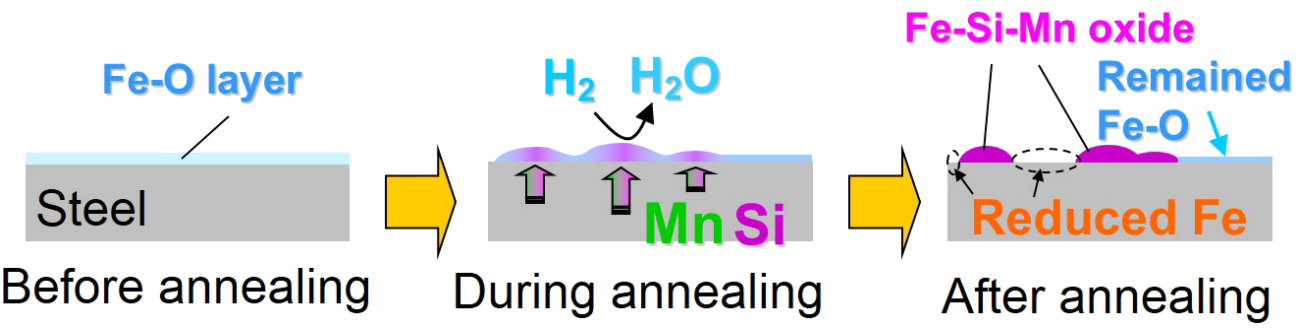

Fig. 13. Schematic illustrations of reduction mechanism of Fe oxide layer at low annealing temperature. (Online version in color.) 
(a)

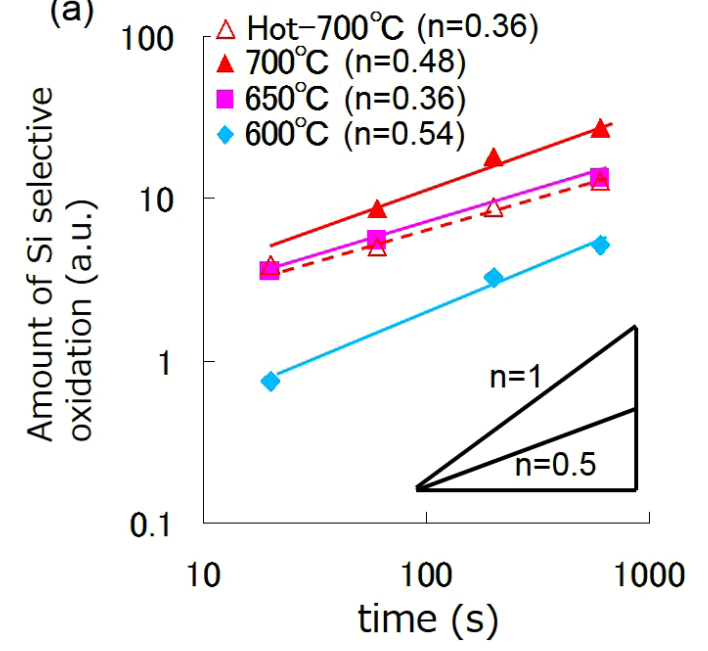

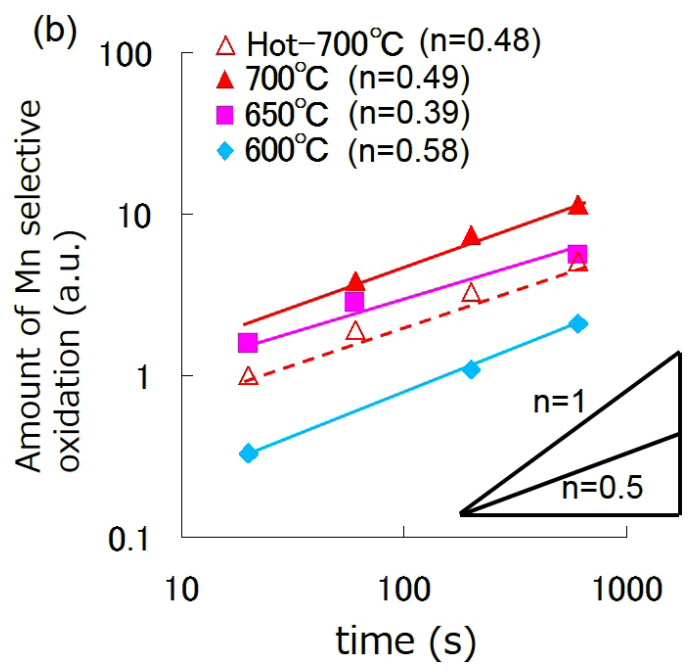

Fig. 14. Time dependence of amount of selective oxidation at surfaces of hot-rolled (annealed at $700^{\circ} \mathrm{C}$ ) and cold-rolled (annealed at $600^{\circ} \mathrm{C}, 650^{\circ} \mathrm{C}, 700^{\circ} \mathrm{C}$ ) steels. (Online version in color.)

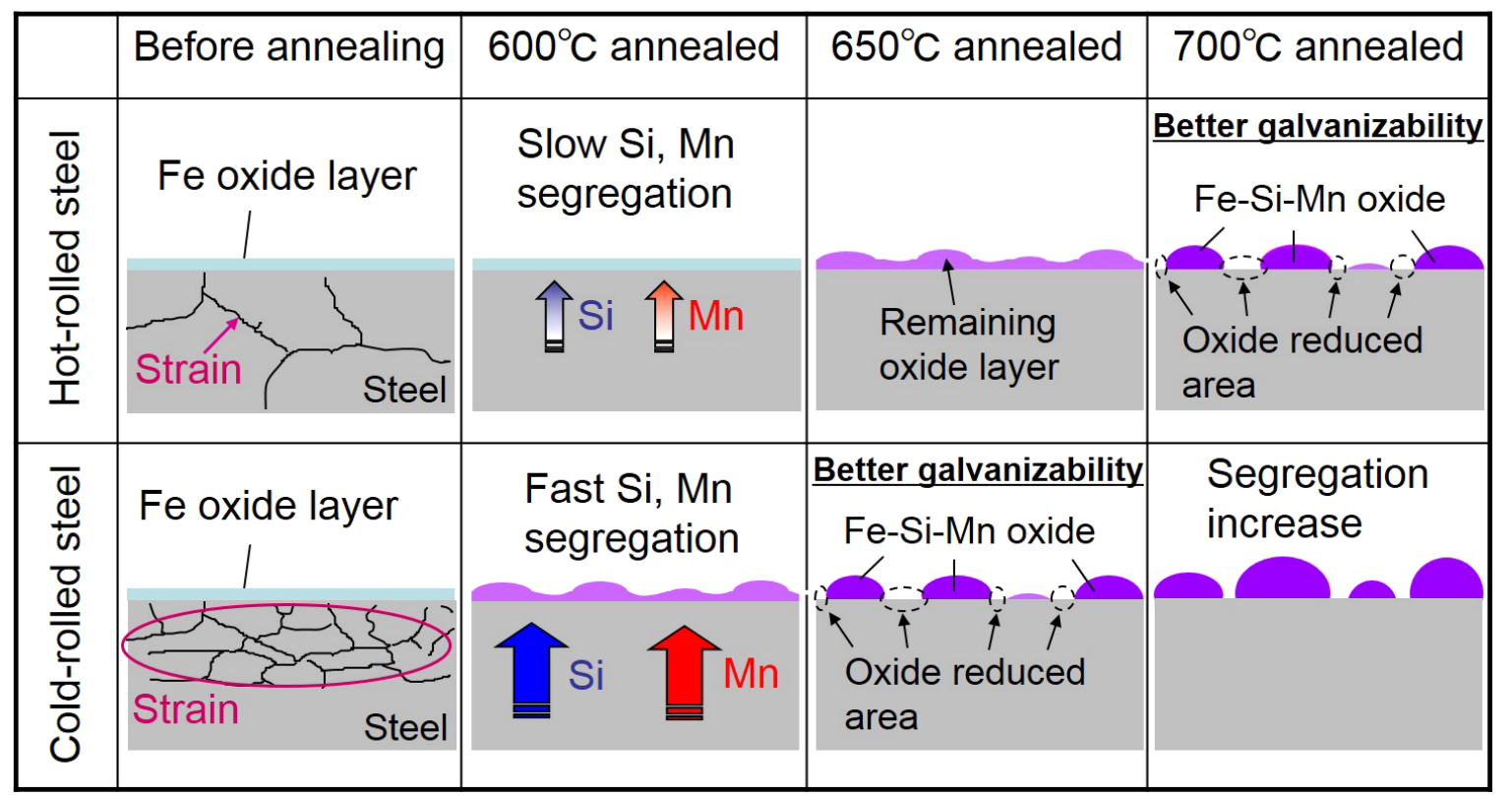

Fig. 15. Schematic illustrations of selective oxidation behavior of hot-rolled and cold-rolled steels annealed at low temperature $\left(600-700^{\circ} \mathrm{C}\right)$. (Online version in color.) in the subsurface region of the hot-rolled steel, as shown in Fig. 5, depletion was considered to have little effect on the segregation rate. Thus, the difference in the segregation rates of the hot-rolled and cold-rolled steels can presumably be attributed to the strained structure that occurred in the cold-rolling process.

Therefore, whether the "diffusion rate" or "reaction rate" is the main determining process of the segregation rate will be discussed in detail in the following paragraph. In order to investigate the time dependence of surface selective oxidation, samples were annealed at the maximum temperature of $600-700^{\circ} \mathrm{C}$ and isothermally heated for an arbitrary time (20-600 s). Above results are shown in Fig. 14. In the figures, " $n$ " represents the slope of the lines estimated by least-squares method, and each line has almost the same value of 0.5 . This result shows that the segregation rates of both $\mathrm{Si}$ and $\mathrm{Mn}$ follow the parabolic law. This means that the segregation rates of $\mathrm{Si}$ and $\mathrm{Mn}$ at low annealing temperatures were determined not by the "reaction rate," but by the "diffusion rate."

The investigation presented the fact that the segregation mechanisms of both the hot-rolled steel and the cold-rolled steel are determined by the "diffusion rate." Therefore, it is suggested that the difference in the segregation rates of $\mathrm{Si}$ and $\mathrm{Mn}$ between the hot-rolled steel and cold-rolled steel is due to strain during the cold-rolling process.

Finally, the difference in $\mathrm{Fe}-\mathrm{Zn}$ reactivity between the hot-rolled steel and the cold-rolled steel in the low annealing temperature region is summarized. On the hot-rolled steel surface, the diffusion rates of $\mathrm{Si}$ and $\mathrm{Mn}$ are so slow that the formation of $\mathrm{Si}-\mathrm{Mn}$ composite oxides is suppressed and the reduction of Fe oxide is also delayed. Therefore, Fe oxide has a large effect on the surface of hot-rolled steel at low annealing temperatures, and as a result, the $\mathrm{Fe}-\mathrm{Zn}$ reactivity of the hot-rolled steel is worse than that of the cold-rolled steel under the same annealing conditions. Moreover, in the case of the hot-rolled steel, a higher annealing temperature is necessary to diffuse sufficient amounts of Si and Mn to 
reduce the $\mathrm{Fe}$ oxide. For these reasons, the $\mathrm{Fe}-\mathrm{Zn}$ reactivity of the hot-rolled steel was substantially worse than that of the cold-rolled steel at low annealing temperatures. Figure 15 shows schematic illustrations of the selective oxidation behaviors of the hot-rolled and cold-rolled steels annealed at low annealing temperatures.

\section{Conclusion}

In order to clarify the factors that affect the galvanizability of hot-rolled and cold-rolled steels, hot-rolled and cold-rolled steel sheets containing 0.7 mass $\%$ Si-1.2 mass $\%$ Mn were annealed at various temperatures in the range of $600-800^{\circ} \mathrm{C}$, and their selective surface oxidation behavior and its effect on $\mathrm{Fe}-\mathrm{Zn}$ reactivity were investigated. The results of the present study are summarized as follows.

(1) As the annealing temperature increased, the Fe$\mathrm{Zn}$ reactivity of both the hot-rolled and cold-rolled steels improved at low annealing temperatures, but deteriorated at high annealing temperatures.

(2) The $\mathrm{Fe}-\mathrm{Zn}$ reactivities of the hot-rolled steel and cold-rolled steel deteriorated with an increasing amount of selectively oxidized $\mathrm{Si}, \mathrm{Mn}$ above $700^{\circ} \mathrm{C}$ and $650^{\circ} \mathrm{C}$, respectively.

(3) At the annealing temperatures lower than $650^{\circ} \mathrm{C}$, a uniform $\mathrm{Fe}$ oxide layer remained on the steel surface, and this layer deteriorated $\mathrm{Fe}-\mathrm{Zn}$ reactivity. It was suggested that this $\mathrm{Fe}$ oxide reacted with $\mathrm{Si}, \mathrm{Mn}$ which diffused from the steel substrate, and orbicular $\mathrm{Si}-\mathrm{Mn}$ oxides were formed. Consequently, the Fe oxide layer was reduced, and the $\mathrm{Fe}-\mathrm{Zn}$ reactivity at low annealing temperatures improved.

(4) The Fe-Zn reactivity of the hot-rolled steel at low annealing temperatures was substantially worse than that of the cold-rolled steel. This can be explained by the slow reduction of $\mathrm{Fe}$ oxide due to the low selective oxidation rate of the hot-rolled steel.

\section{REFERENCES}

1) A. Andoh, J.-i. Uchida, H. Entani, C. Kato, H. Kuroda, T. Satou, M. Shimizu, S. Fujita, A. Miyasaka, Y. Morimoto and M. Yamashita: Tetsu-to-Hagané, 89 (2003), 3 (in Japanese).

2) M. Takahashi: Tetsu-to-Hagané, 100 (2014), 82 (in Japanese).

3) Y. Kawasaki, T. Nakagaito, S. Kaneko, S. Takagi, S. Matsuoka and Y. Tanaka: CAMP-ISIJ, 21 (2008), 1331, CD-ROM (in Japanese).

4) Y. Kuriyama, M. Takahashi and H. Ohashi: J. Soc. Automot. Eng. Jpn., 55 (2001), 51 (in Japanese).

5) L. Zhou, D. Zhang and Y. Liu: Int. J. Miner. Metall. Mater., 21 (2014), 755.

6) Y. Hirose, H. Togawa and J. Sumitani: Tetsu-to-Hagané, 68 (1982), 665 (in Japanese).

7) C. Kato, T. Sekine, S. Umino, T. Yamashita, K. Mochizuki and M. Masuda: CAMP-ISIJ, 7 (1994), 1511 (in Japanese).

8) I. Hashimoto, K. Saito, M. Nomura, T. Yamamoto and H. Takeda: Tetsu-to-Hagané, 89 (2003), 31 (in Japanese).

9) S. Shimada, Y. Takada, J. Lee and T. Tanaka: Tetsu-to-Hagané, 93 (2007), 5 (in Japanese).

10) T. Kawano and F. U. Renner: ISIJ Int., 51 (2011), 1703.
11) M. Blumenau, A. Barnoush, I. Thomas, H. Hofmann and H. Vehoff: Surf. Coat. Technol., 206 (2011), 542.

12) I. Cvijovic, I. Parezanovic and M. Spiegel: Corros. Sci., 48 (2006), 980.

13) J. Lee, J. Park and S. Jeon: Metall. Mater. Trans. B, 40 (2009), 1035.

14) Tekko Binran, Vol. III, Atuen Kiso Kohan, 3rd ed., ed. by ISIJ, Maruzen, Tokyo, (1980), 449 (in Japanese).

15) Netuen Kohan Manual, ed. by Netuen Kohan Bukai, ISIJ, Tokyo, (2000), 43 (in Japanese).

16) M. Takeda, T. Oonishi, Y. Mukai and T. Soshiroda: Kozai Hyoumen Tokusei ni oyobosu Scale Seijyo no Eikyou, ISIJ, Tokyo, (2005), 57 (in Japanese).

17) H. S. Raymond, F. Bertran and D. Huin: Proc. 6th Int. Conf. on Zinc and Zinc Alloy Coated Steel Sheet (GALVATECH '04), AIST, Warrendale, PA, (2004), 383.

18) H. S. Raymond, D. Bettinger, Ph. Osmont and J. C. Denquin: Proc. 7th Int. Conf. on Zinc and Zinc Alloy Coated Steel Sheet (GALVATECH '07), ISIJ, Tokyo, (2007), 279.

19) S. P. Mattew and P. C. Hayes: Metall. Trans. B, 21 (1991), 141.

20) C. Guan, J. Li, N. Tan, Y. Q. He and S. G. Zhang: Int. J. Hydrog. Energy, 39 (2014), 15116.

21) S. Feliu, Jr. and M. L. Perez-Revenga: Metall. Mater. Trans. A, 35 (2004), 2039.

22) L. Bordignon: Proc. 5th Int. Conf. on Zinc and Zinc Alloy Coated Steel Sheet (GALVATECH '01), Verlag Stahleisen, Düsseldorf, (2001), 19.

23) S. Claessens, R. Steffen, S. Fernandez, P. V. Hasselt and L. Garidis: Proc. 5th Int. Conf. on Zinc and Zinc Alloy Coated Steel Sheet (GALVATECH '01), Verlag Stahleisen, Düsseldorf, (2001), 631.

24) A. Chattopadhyay, V. S. Sarma, B. S. Murty, D. Bhattacharjee and M. Dutta: Proc. 7th Int. Conf. on Zinc and Zinc Alloy Coated Steel Sheet (GALVATECH '07), ISIJ, Tokyo, (2007), 291.

25) A. Chattopadhyay, V. S. Sarma, B. S. Murty, A. Haldar and D. Bhattacharjee: Scr. Mater., 59 (2008), 522

26) A. Chattopadhyay, V. S. Sarma, B. S. Murty, A. Haldar and D. Bhattacharjee: Surf. Coat. Technol., 203 (2009), 3465.

27) D. Hierzenberger, A. Jarosik, R. Pree, M. Sonnleitner, B. Linder, J. Wagner, E. Achammer, Th. Haunschmied and G. Angeli: Proc. 8th Int. Conf. on Zinc and Zinc Alloy Coated Steel Sheet (GALVATECH '11), AIM, Milano, (2011), 153.

28) K. Nishimura, H. Odashima, K. Kishida and M. Oda: Tetsu-toHagané, 79 (1993), 187 (in Japanese).

29) K. Nishimura, H. Odashima, K. Kishida and M. Oda: Tetsu-toHagané, 79 (1993), 590 (in Japanese).

30) Y. Takada, M. Suehiro, M. Sugiyama and T. Senuma: Tetsu-toHagané, 92 (2006), 21 (in Japanese).

31) Y. Takada, M. Suehiro, Y. Ikematu and K. Tanaka: Tetsu-to-Hagané, 94 (2008), 19 (in Japanese).

32) Y. Hirose, H. Togawa and J. Sumiya: Tetsu-to-Hagané, 68 (1982), 658 (in Japanese).

33) I. Olefjord, W. Leijon and U. Jelvestam: Appl. Surf. Sci., 6 (1980), 241.

34) O. Kubaschewski, E. Ll. Evans and C. B. Alcock, trans. by K. Tanba, S. Yokokawa and Y. Nakamura: Kinzoku Netsu Kagaku, Sangyo Tosho, Tokyo, (1968), 345 (in Japanese).

35) Kinzoku Zairyo no Koon Sanka to Koon Fushoku, ed. by Fushoku Boushoku Kyokai, Maruzen, Tokyo, (1982), 139 (in Japanese).

36) Y. Suzuki, Y. Sugimoto and S. Fujita: Tetsu-to-Hagané, 93 (2007), 489 (in Japanese).

37) M. Isobe, K. Kyono and N. Totsuka: CAMP-ISIJ, 8 (1995), 649 (in Japanese).

38) M. Isobe, K. Kyono and C. Kato: CAMP-ISIJ, 10 (1997), 608 (in Japanese).

39) Y. Fushiwaki, Y. Nagataki, H. Nagano, W. Tanimoto and Y. Sugimoto: ISIJ Int., 54 (2014), 664.

40) C. F. McConville, D. L. Seymour, D. P. Woodruff and S. Bao: Surf. Sci., 188 (1987), 1

41) L. J. Cuddy and W. C. Leslie: Acta Metall., 20 (1972), 1157.

42) I. Masumoto and H. Hira: J. Jpn. Weld. Soc., 50 (1981), 284 (in Japanese).

43) M. Nagano, T. Miyazawa, Y. Mikami, K. Kanaya and Y. Shinniwa: J. High Press. Inst. Jpn., 39 (2001), 337 (in Japanese). 